\title{
MENJADIKAN PERIKANAN BUDIDAYA SEBAGAI INKUBATOR BISNIS MANDIRI: PELAJARAN BERHARGA DARI TAIWAN
}

\author{
Estu Nugroho \\ Balai Riset Perikanan Budidaya Air Tawar \\ Jl. Raya Sempur No. 1, Bogor 16154 \\ E-mail: brpbat@yahoo.com
}

\begin{abstract}
ABSTRAK
Keberhasilan Taiwan dalam bidang budidaya perikanan merupakan suatu hal yang dapat dijadikan contoh pembelajaran dalam pengembangan budidaya di Indonesia, dengan penyesuaian keadaan di Indonesia. Pada prinsipnya keberhasilan Taiwan dipengaruhi oleh beberapa faktor, di antaranya adalah: kejelian dalam memilih komoditas, kesuksesan penerapan teknologi tepat guna serta peranan yang kuat dari pemerintah, perguruan tinggi, dan asosiasi dalam bidang perikanan. Komoditas yang mempunyai nilai ekonomis yang tinggi menjadi acuan pengembangan produk khususnya ekspor. Teknologi dengan memanfaatkan bahan baku serta sumberdaya alam yang ada di daerah setempat merupakan andalan pembudidaya dalam menaikkan produktivitas melalui penyediaan air yang berkualitas, pakan yang ramah lingkungan, benih yang berkualitas serta penggunaan bahan herbal untuk kekebalan. Penyediaan infrastruktur sarana dan prasarana, penyediaan dana yang mudah dan murah serta jalur transfer teknologi yang jelas mempunyai peranan yang penting.
\end{abstract}

KATAKUNCl: budidaya, inkubator bisnis, Taiwan

\section{PENDAHULUAN}

Taiwan atau dikenal sebagai Republic of China (berbeda dengan Republik Rakyat Cina), merupakan suatu negara pulau yang mempunyai luas wilayah sedikit lebih besar dari Pulau Jawa (35.961 km²). Namun demikian, produktivitas negara tersebut dalam bidang perikanan budidaya sangat baik, sekitar 331.000 MT (Fisheries Agency, 2008). Keberhasilan budidaya di Negara Taiwan ini, tidak terlepas dari keseriusan dan konsistensi semua pihak yang terlibat atau mempunyai andil di bidang ini. Pihak pemerintah bekerja sama dengan swasta, baik secara perorangan maupun melalui asosiasi, terus berpacu secara serentak membangun perikanan budidaya di negara tersebut.

Perkembangan teknologi yang modern serta aplikatif untuk mendukung kegiatan bisnis perikanan budidaya secara serempak dituangkan dalam program-program yang nyata dengan memanfaatkan berbagai kelengkapan yang dimiliki oleh universitas-universitas terkemuka di seluruh Taiwan yang mempunyai tenaga pengajar yang mumpuni di bidangnya dan sebagian besar lulusan universitas terkemuka luar negeri.

Pembentukan jaringan informasi yang handal serta akurat menjadikan pelaku-pelaku budidaya di Taiwan sangat mengerti akan keadaan pasar maupun sumberdaya perikanan yang sedang ataupun akan menjadi idola di dunia perikanan budidaya di tingkat dunia. Hal ini membantu mereka mengoptimalkan upaya yang sedang mereka lakukan dalam membangun perikanan budidaya sebagai salah satu inkubator bisnis yang mandiri dan bankable.

Berikut ini beberapa hal yang dapat dijadikan perbandingan serta pelajaran dalam rangka membangun perikanan budidaya di Indonesia, khususnya pengembangan budidaya ikan air tawar yang mempunyai cakupan yang sangat luas di masyarakat.

\section{KOMODITAS}

Strategi yang digunakan oleh Taiwan untuk mengembangkan perikanan budidaya adalah dengan memilih komoditas budidaya secara tepat. Salah satu kriteria yang digunakan adalah komoditas tersebut mempunyai nilai ekonomis yang tinggi tidak hanya untuk kepentingan pasar dalam negeri namun utamanya untuk pasar ekspor.

Secara umum, hanya ikan-ikan dengan harga jual tinggi yang terlihat banyak di kolam-kolam masyarakat di Taiwan, antara lain kerapu, udang windu, udang vaname, dan napoleon (perikanan laut), sedangkan ikan air tawar didominasi oleh ikan sidat Jepang dan ikan nila merah (Yang et al., 2009). 

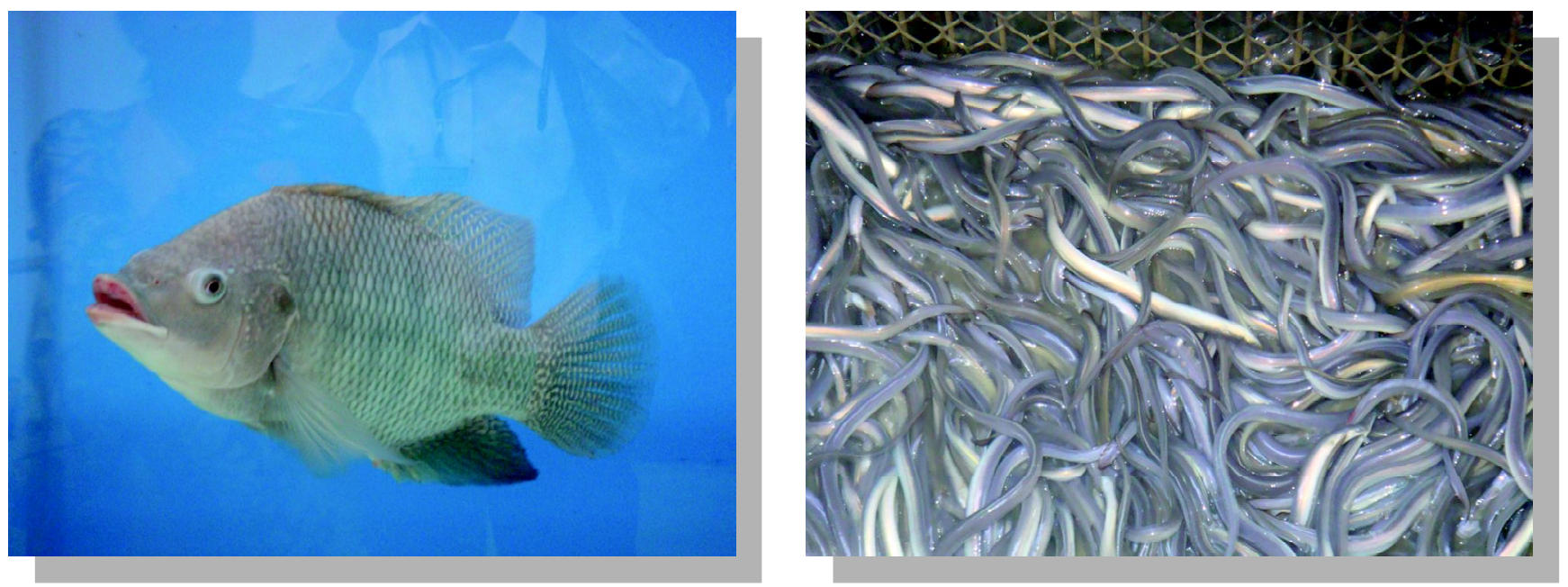

Gambar 1. Jenis komoditas yang dikembangkan oleh pembudidaya di Taiwan, nila (kiri) dan sidat (kanan)

Ikan-ikan jenis lain terutama yang merupakan endemik tetap dikembangkan tapi oleh lembaga pemerintah. Sehingga masyarakat hanya berkonsentrasi dan mencurahkan tenaga untuk pengembangan komoditaskomoditas ekonomis di atas. Hal ini memudahkan monitoring dan evaluasi kegiatan budidaya di Taiwan berdasarkan komoditasnya.

Kenyataan ini berbeda dengan upaya kegiatan budidaya di Indonesia. Seperti diketahui berbagai potensi komoditas yang ada di tanah air digarap secara bersamaan sehingga seringkali memerlukan waktu yang relatif lebih lama untuk penuntasannya. Bahkan terkadang pengkajiannya menjadi terkendala oleh minimnya dana yang tidak seberapa besar dibagi untuk jumlah komoditas yang sagat besar. Tercatat, di samping komoditas utama udang, rumput laut, nila, dan lele, beberapa komoditas juga gencar dikembangkan seperti gurame, nilem, belida, mahseer, baung, patin, dan lain-lain tergantung policy daerah masing-masing.

Bercermin dari keberhasilan Taiwan dalam mengelola komoditas yang dimiliki, memang sudah selayaknya secara nasional penentuan komoditas ini perlu dilandasi pengkajian yang matang secara komprehensif berdasarkan kriteria yang teruji, apakah kebutuhan pasar. Teknologi ataupun ketersediaan stok yang ada di Indonesia.

\section{TEKNOLOGI YANG APLIKATIF}

Setelah berkunjung ke berbagai farm baik yang membudidayakan ikan laut maupun ikan tawar, pada umumnya para pelaku bisnis di Taiwan sudah menggunakan teknologi yang tepat guna serta berwawasan lingkungan.
Penemuan dan pengkajian teknologi yang aplikatif ini diperoleh dengan mengoptimalkan kerja sama antara lembaga riset di UPT pemerintah maupun universitas dengan pengusaha yang berminat di bidangnya. Sehingga hasil-hasil penelitian tidak lagi menjadi sekedar arsip untuk disimpan di bawah meja melainkan sebagai alat untuk diterapkan secara langsung di berbagai bidang bisnis. Hal ini memacu para peneliti untuk lebih berkarier di bidangnya secara total, selain memberikan kepuasan batin juga secara material.

Teknologi-teknologi yang ditemukan pada umumnya menggunakan aplikasi bioteknologi yang memerlukan bantuan mikroorganisme semacam bakteri. Beberapa produk yang telah diaplikasikan adalah penggunaan probiotik dalam budidaya, imunostimulan dan vaksin.

Secara garis besar, pendekatan teknologi yang diterapkan oleh para pembudidaya di Taiwan adalah dengan menerapakan konsep WASD yang merupakan singkatan dari Water, Aquafeed, Seeds, dan Disease. Adapun penjelasan secara ringkas adalah sebagai berikut:

\section{Water (air)}

Prinsip dasar yang digunakan adalah memanfaatkan air sebagai media pemeliharaan ikan seefisien mungkin. Para pembudidaya tidak akan memasukkan benih untuk dipelihara sebelum air yang memenuhi kriteria baik untuk budidaya terpenuhi baik secara kualitas maupun kuantitas.

Oleh sebab itu, hampir seluruh pembudidaya ikan air tawar di Taiwan menggunakan air tanah sebagai sumber media pemeliharaan ikan. Kenyataan ini dapat dimengerti karena air tanah dapat diibaratkan telah mengalami filterisasi secara tidak langsung oleh lapisan tanah. 
Sehingga pada kedalaman tertentu (umumnya > $100 \mathrm{~m}$ ) air yang tersedia telah benar-benar bersih. Kemungkinan yang kurang hanyalah kandungan oksigen yang rendah. Keadaan ini diatasi oleh para pembudidaya dengan menggunakan kincir air (pedal wheel) atau pompa air sebagai pemasok kandungan oksigen (Gambar 2).

Pemanfaatan sumber air dari laut dalam (deep sea water) telah banyak diaplikasikan untuk budidaya udang. Di mana air laut diambil dari kedalaman sekitar 500-600 m dari permukaan air laut perairan Kurosio. Sumberdaya lainnya di daerah ini juga mulai dikaji secara mendalam.

Penggunaan seefisien mungkin oleh pembudidaya ikan dengan hanya menambah kekurangan air karena evaporasi (porositas tidak terjadi karena dasar kolam juga diperkeras dengan menggunakan semen) antara 1\%3\%dari volume total setiap hari. Hal ini memaksa pembudidaya untuk memelihara kualitas air yang digunakan sebaik mungkin dengan menambahkan probiotik. Ada dua jenis bakteri yang digunakan yaitu bakteri pengurai bahan organik yaitu sejenis bacilus dan bakteri penurun konsentrasi pirit. Dewasa ini penggunaan bakteri sebagai penambah proses fotosintesis juga mulai digunakan.

Dengan memanfaatkan produk hasil bioteknologi ini para pembudidaya dapat menggunakan air secara terusmenerus untuk budidaya tanpa harus mengganti sebagian besar air media seperti di Indonesia. Kualitas air terjaga dengan baik, di mana secara kasat mata terlihat dari warnanya yang hijau penuh dengan plankton sebagai sumber pakan alami. Maka tidak mengherankan pada hasil pembesaran ikan nila merah di kolam tembok tersebut mempunyai rasio konversi pakan (Feed Conversion Ratio) sebesar 0,9-1,0.

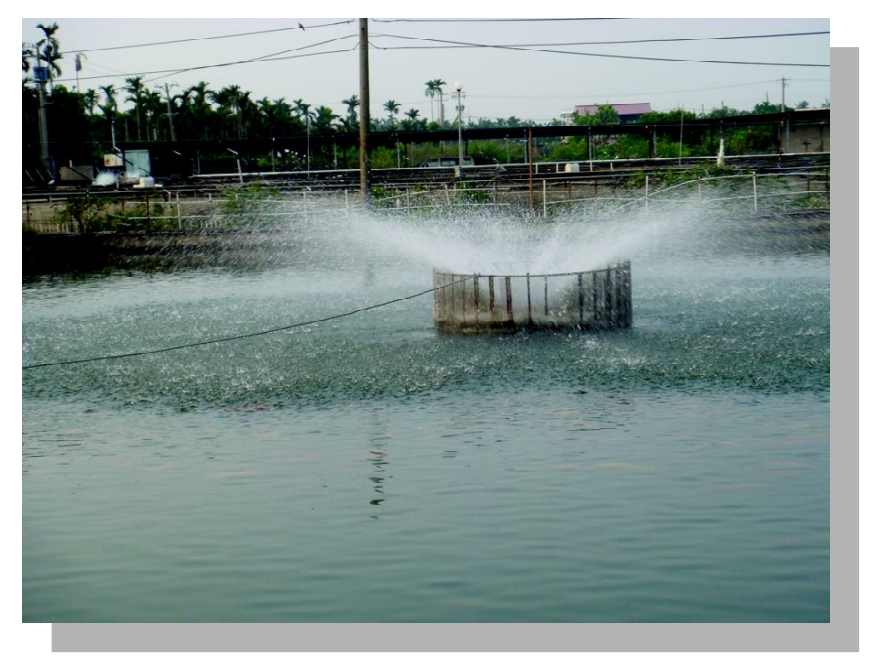

Gambar 2. Kolam pemeliharaan ikan nila merah dengan teknologi tepat guna

\section{Aquafeed (Pakan)}

Pakan digunakan sebagai sumber energi disesuaikan dengan keadaan umur ikan yang dikenal sebagai pakan secara fungsional. Pakan untuk induk, larva, benih, dan pembesaran berbeda-beda disesuaikan dengan kebutuhan masing-masing stadia dan jenis ikan.

Pakan yang digunakan juga diusahakan berbahan baku local dan ramah lingkungan sehingga kebersinambungan dari usaha budidaya dapat terjaga. Penggunaan bakteri sebagai pembantu proses pencernaan juga mulai dilakukan sehingga pakan menjadi lebih mudah dicerna.

Peningkatan kualitas bahan pakan yang berasal dari sisa-sisa atau limbah dilakukan sebagai alternatif sumber protein pengganti tepung ikan yang semakin meningkat harganya. Bahkan terkadang pakan-pakan tersebut diperkaya dengan imunostimulan yang meningkatkan daya tahan terhadap serangan patogen.

Efektivitas penggunaan pakan juga dilakukan dengan hanya memberikan pakan yang berkualitas baik, dengan jumlah yang tepat. Pakan apung lebih banyak digunakan menggantikan pakan tenggelam, karena kemudahan dalam monitoring pemanfaatannya. Di mana keadaan sebaliknya terjadi di Indonesia karena faktor harga pakan yang berbeda antara pakan apung dan tenggelam.

\section{Seeds (Benih)}

Benih dengan kualitas baik dan bersertifikat merupakan satu persyaratan untuk keberhasilan usaha budidaya perikanan. Benih yang beredar dan digunakan oleh para pembudidaya di Taiwan umumnya berasal dari instansi atau perusahaan yang telah diakui secara resmi dan bersertifikat.

Benih-benih ikan tersebut telah mengalami pengkajian yang baik melalui penerapan program domestikasi dan pemuliaan yang jelas dan terukur, bahkan penggunaan teknologi yang lebih tinggi, misalnya seperti transgenik sudah berhasil dilaksanakan. Namun demikian penerapan metode ini secara massal masih belum tepat waktunya mengingat masih banyak persepsi masyarakat yang berbeda mengenai hal ini.

Beberapa jenis komoditas ikan yang merupakan hasil domestikasi dan pemuliaan yang telah beredar adalah ikan kerapu dan nila merah. Seorang pembenih di daerah Tungkang telah mengumpulkan hampir semua jenis ikan kerapu dari daerah Philippina, Indonesia, dan beberapa wilayah yang dikenal mempunyai stok ikan ini di perairan alaminya. Jenis-jenis ikan kerapu yang telah berhasil didomestikasi antara lain kerapu. 
Sedangkan ikan nila merah dan beberapa nila hitam hasil pemuliaan telah diproduksi secara massal oleh institusi penelitian di daerah Taiwan Tengah. Ikan nila merah dihasilkan dengan menyilangkan ikan nila betina 0. mossambicus dengan ikan nila jantan 0. niloticus. Ikan nila supermale diproduksi dari penyilangan antara ikan nila betina 0 . aureous dengan ikan nila jantan 0 . niloticus.

Program domestikasi ternyata tidak hanya dilakukan untuk komoditas-komoditas yang telah mempunyai nilai ekonomis yang tinggi, namun juga dilakukan pada jenisjenis ikan asli perairan Taiwan. Kegiatan domestikasi ikan endemik ini umumnya dikerjakan oleh institusi riset pemerintah.

\section{Disease (Penyakit)}

Prinsip yang diterapkan utuk mengatasi masalah penyakit yang beredar (jika ada) di budidaya ikan di Taiwan adalah sedapat mungkin mencegah dengan memanfaatkan bahan-bahan yang bersifat alami dan tidak berbahaya. Penggunaan bahan-bahan herbal yang berasal dari daratan Cina telah dalam pengujian yang menyeluruh.

Peningkatan kekebalan benih ikan sebelum dipelihara dalam budidaya telah dijadikan prosedur standar oleh para pembudidaya. Produksi benih ikan dan udang yang resisten terhadap patogen spesifik dilakukan baik melalui program pemuliaan maupun pembuatan imunostimulan dan vaksin.

Monitoring dan pengawasan hal-hal yang dapat menimbulkan penyakit dilakukan secara ketat dengan melibatkan seluruh unsur yang berperan dalam usaha budidaya. Penggunaan obat-obatan jika terpaksa dilakukan hanya menggunakan jenis obat yang tidak termasuk dalam daftar yang dilarang oleh masyarakat Internasional. Penggunaan obat-obatan ini seringkali diikuti dengan proses detoksifikasi sebelum dipasarkan.

\section{PASAR, DIVERSIFIKASI PRODUK, DAN SEGMENTASI USAHA}

Seperti telah disebutkan di atas, komoditas yang diproduksi oleh pembudidaya adalah ikan-ikan dengan nilai ekonomis yang tinggi. Pada umumnya sasaran produksi ini sebagian besar ditujukan untuk pasar ekspor.

Taiwan mempunyai keuntungan untuk bersaing dengan negara lain yaitu letaknya yang lebih dekat dengan pasar. Pasar utama produk mereka (kerapu, sidat, dan nila merah) adalah Hongkong, Cina, Korea, dan Jepang. Untuk pasar dalam negeri hanya jenis-jenis ikan laut lainnya yang banyak mereka konsumsi.
Upaya diversifikasi produk selain penjualan dalam bentuk hidup, beku, dan filet telah mulai banyak dirintis. Beberapa produk yang cukup menarik perhatian adalah es krim yang terbuat dari udang, rumput laut, cumi, dan tinta cumi, dan beberapa jenis minuman ataupun obatobatan untuk kecantikan.

Keberhasilan program diversifikasi ini salah satunya ditunjang oleh adanya kerja sama antara institusi riset baik yang ada di perguruan tinggi maupun di instansi pemerintah dengan pihak pengusaha yang berminat untuk produksi massal dan komersial hasil riset yang ada. Di mana keberlangsungan kerja sama ini juga mempunyai impak yang telah dapat menunjang keberhasilan peneliti dalam berkarier (materi).

Usaha budidaya yang teratur dan apik ini ternyata juga sebagai akibat adanya segmentasi usaha yang dilakukan oleh pembudidaya. Dengan segmentasi ini maka kecepatan perputaran modal menjadi lebih efisien dibandingkan dengan usaha dari awal hingga akhir secara simultan karena mereka menjadi lebih fokus menangani usahanya. Namun demikian, segmentasi ini memerlukan suatu komitmen yang kuat serta keseriusan yang tinggi dalam menjalankannya, jika tidak, maka akan mengganggu jalannya rantai usaha berikutnya.

\section{DUKUNGAN PEMERINTAH DAN ASOSIASI}

Pemerintah Taiwan mempunyai peranan yang penting dalam pengembangan budidaya perikanan melalui dukungannya dengan pembuatan fasilitas-fasilitas infrastruktur serta perijinan yang sederhana. Tahun 2008, suatu kawasan pengembangan bioteknologi yang mendukung pertanian dalam artian secara luas telah selesai dilaksanakan.

Kawasan semacam itu diperuntukkan sebagai alternatif untuk menyiasati persaingan global yang semakin keras. Pemerintah menyediakan semua kebutuhan untuk industri bioteknologi, dan pihak swasta yang memanfaatkan dengan mendirikan pabrik atau kebun dan kolam produksi di daerah tersebut. Tempat tersebut juga dilengkapi kantor perijinan termasuk karantina sehingga pengusaha dapat langsung melakukan ekspor langsung dari kawasan tersebut.

Dukungan asosiasi yang mengurusi perikanan juga dirasakan sangat vital. Asosiasi yang didirikan oleh para pelaku perikanan membantu para anggotanya dalam segala hal, mulai dari segi teknis hingga penyediaan dan melalui bank yang dimiliki dengan fasilitas kredit lunak. Sehingga bidang perikanan yang terkenal dengan risiko tinggi untuk 
perbankan tidak mengalami kesulitan dalam mencari sumber dana.

Selain itu, asosiasi tersebut juga bertindak dalam pemberian informasi secara dini tentang perikanan kepada anak-anak melalui museum yang didirikannya. Pengenalan bidang perikanan kepada masyarakat secara luas ini mempunyai pengaruh yang nyata kepada pengembangan budidaya di mana masyarakat sejak dini diperkenalkan kepada pentingnya ikan bagi kehidupan. Produk-produk yang dikemas dengan baik juga dilakukan oleh asosiasi sebagai pendukung upaya pemasaran di dalam negeri.

Asosiasi ini juga yang membantu perjuangan para anggotanya jika terjadi suatu permasalahan atau musibah. Taiwan terkenal dengan musibah angin taufan, dan para nelayan dan pembudidaya yang sering terkena dampak langsung seperti banjir dan tidak melaut. Jika hal tersebut terjadi maka asosiasi berjuang untuk mendapatkan keringanan kewajiban pajak dari pemerintah bahkan jika diperlukan mendapatkan bantuan sebagai pengganti kerugian yang dirasakan anggotanya.

\section{BAGAIMANA PERKEMBANGAN BUDIDAYA PERIKANAN DI INDONESIA?}

Dewasa ini, budidaya perikanan diharapkan menjadi tulang punggung dari sektor perikanan mengingat produksi hasil perikanan tangkap semakin merosot. Perkembangan budidaya baik laut, payau dan tawar telah berkembang cukup baik. Namun demikian karena adanya beberapa permasalahan di bidang penyakit, khsususnya perkembangan budidaya payau (udang) mengalami kemerosotan yang cukup tajam, hanya beberapa kawasan budidaya udang windu yang tetap beroperasi walaupun kembali menggunakan sistem tradisional dan semi intensif.

Secara nasional hanya 4 komoditas yang dijadikan andalan di bidang budidaya yaitu udang, nila, rumput laut, dan catfish. Jumlah ini meningkat jika masing-masing daerah mempunyai komoditas tambahan lainnya sampai menjadi 15 komoditas antara lain, gurame, patin, baung, nilem, mas, belida, betutu, tambakan, semah, tengadah, serta papuyu.

Berdasarkan pertimbangan masing-masing daerah pemilihan komoditas tersebut tidak salah, namun seringkali beberapa Pemerintah daerah terpengaruh untuk menentukan suatu komoditas menjadi pilihan utama walaupun secara ekonomis tidak layak dikembangkan sebagai bahan bisnis.
Sebagai misal, karena peluang pasar yang cukup besar serta tradisi yang telah melekat lama di wilayah Jawa Barat akan kebutuhan ikan mas dan nila banyak pembudidaya yang berkiprah dalam budidaya ikan mas dan nila, terutama di daerah Cirata. Pada kenyataannya, dewasa ini, harga jual produk tersebut tidak setara dengan biaya produksi sehingga secara bisnis tidak layak. Terlebih lagi, lingkungan pemeliharaan di KJA sudah merosot tajam kualitasnya sehingga mengurangi produktivitas.

Hal lainnya adalah penggunaan air yang sebagian besar berasal dari sungai yang dimanfaatkan oleh banyak bidang. Penggunaan air dengan kepentingan yang berbeda-beda ini mempunyai beberapa kelemahan di antaranya adalah kualitas air yang tidak dapat dikontrol sehingga mempengaruhi produksi yang dihasilkan. Sumber air lainnya dengan kualitas yang baik perlu dipertimbangkan dalam pengembangan budidaya di masa datang.

Penerapan teknologi yang tepat guna perlu dipertimbangkan dalam pengembangan budidaya di Indonesia. Teknologi yang dimodifikasi dan disesuaikan dengan keadaan lingkungan alam serta sumberdaya lainnya di daerah tertentu akan dapat menekan biaya produksi sehingga margin yang didapat akan menjadi lebih besar, sehingga dapat memacu pengembangan budidaya oleh masyarakat secara mandiri.

Faktor lainnya yang dirasakan masih perlu ditingkatkan adalah dukungan pemerintah dan pembentukan kelembagaan yang dinamis dalam membantu para pembudidaya. Keduanya mempunyai pengaruh yang nyata dalam memacu pengembangan budidaya di daerah. Penyediaan fasilitas sarana dan prasarana serta pendanaan merupakan aspek yang sangat diharapkan oleh pembudidaya. Sedapat mungkin pembudidaya tidak terlalu diberatkan oleh hal-hal yang dapat mengganggu pengembangan budidaya melalui semakin tingginya biaya produksi suatu komoditas.

\section{DAFTAR ACUAN}

Fisheries Agency (2007, 2008). Taiwan Fisheries Yearbook. Taipei, Taiwan. R.O.C.

Yang Shuenn-Der, Fu-Guang Liu, Ting-Shih Huang, RueyLiang Chou, Ren-Shyang Tai, \& Mao-Sen Su. Country Report in Meeting of Application of Advanced Technology in Aquaculture. Asian Productivity Organization held in Taiwan, 19-23 October 2009. 